\title{
Immunohistochemical demonstration of CD23 expression on lymphocytes in rheumatoid synovitis
}

\author{
E A Hellen, D C Rowlands, T T Hansel, G D Kitas, J Crocker
}

\begin{abstract}
The leucocyte antigen CD23 is expressed by $B$ lymphocytes following activation by a number of stimuli and functions as an IgE receptor, and in its soluble form, as a putative $B$ cell growth factor. The expression of CD23 on the surface of lymphocytes in paraffin wax sections of synovial biopsy specimens was studied using a novel mouse monoclonal antibody, BU38. Specimens were investigated from nine cases of rheumatoid arthritis, six cases of osteoarthritis, and eight cases of chronic inflammation in articular and non-articular tissues. CD23 was expressed on a high proportion of lymphocytes in all forms of chronic inflammation and was not specific for rheumatoid arthritis. It may be a characteristic feature of any chronic inflammatory response. As CD23 was found on the surface of lymphocytes in many cases of these arthritides, ${ }^{-C D 23}$ in serum or synovial fluid may yet prove a useful marker for the severity of the inflammatory infiltrate.
\end{abstract}

Rheumatoid arthritis is a chronic inflammatory disease which predominantly affects synovial tissues, resulting in irreversible articular damage and loss of function. Most patients with rheumatoid arthritis have serum rheumatoid factors consisting of immunoglobulins with specificity for the Fc fragment of IgG. Synovial lymphocytes have the capacity to produce rheumatoid factors, and the rheumatoid synovium is infiltrated with activated $B$ and $T$ cells. ${ }^{12}$ A lymphocytic infiltrate is also seen, however, in other chronic synovitides. ${ }^{34}$ Although the aetiology of rheumatoid arthritis is unknown, there is an association with HLA DR4, ${ }^{56}$ and a defect in cellular immunity with abnormal production of and response to cytokines has been postulated. ${ }^{78}$ Certain infectious agents including Epstein Barr virus (EBV) have also been implicated in the pathogenesis of the disease. $^{9-11}$

The low affinity IgE receptor (CD23) is a 45 kilodalton molecule expressed on $\operatorname{IgM} / \operatorname{IgD}$ bearing $B$ lymphocytes following activation, ${ }^{12} 13$ as well as on a number of other cell types including follicular dendritic cells and Langerhans' cells. ${ }^{1214-16}$ CD23 expression on
B lymphocytes is particularly increased following infection by EBV, ${ }^{17}$ but also occurs after activation by a number of other stimuli such as interleukin 4 and so is not specific to EBV infection. ${ }^{12} \mathrm{CD} 23$ also exists in a $25-30$ kilodalton soluble form (sCD23) that is secreted or can be formed by cleavage of surface CD23. ${ }^{18}$ This $\mathrm{SCD} 23$ has been suggested to have autocrine B lymphocyte growth factor activity, ${ }^{1920}$ although gene cloned sCD23 does not have this property. ${ }^{21}$

In this study we investigated the expression of CD23 by lymphocytes in paraffin wax embedded synovial biopsy specimens from patients with rheumatoid arthritis and osteoarthritis. Several specimens of other tissues showing chronic inflammation were also studied. A novel mouse monoclonal antibody, BU38, with the particular advantage of being able to visualise CD23 in paraffin wax sections ${ }^{22}$ was used.

\section{Methods}

Archival paraffin wax embedded synovial biopsy specimens were obtained from the Department of Histopathology, East Birmingham Hospital. All sections of each specimen were reviewed, and those showing changes of chronic inflammation with a prominent chronic inflammatory cell infiltrate were chosen for further study. These included nine cases of rheumatoid arthritis, six of osteoarthritis, and three cases of non-specific synovial inflammation. The clinical case notes of all these patients were reviewed to confirm these diagnoses. Particular note was made of the rheumatoid factor concentration, radiological changes, the presence of morning stiffness, haemoglobin concentration and erythrocyte sedimentation rate (ESR) as indices of disease activity at the time of the biopsy.

Five biopsy specimens showing chronic inflammation in other tissues were also chosen for study. These consisted of non-specific dermatitis, chronic cholecystitis, branchial cyst, Crohn's disease of the ileum and chronic gastritis.

All the specimens had been fixed for at least 18 hours in $10 \%$ formol-saline and then processed as for routine histological examination. Sections were cut at $3 \mu \mathrm{m}$ thickness, attached to glass slides, and incubated at $40^{\circ} \mathrm{C}$ for 18 hours and then dewaxed and
Correspondence to: Dr J Crocker

Accepted for publication 23 October 1990 
Table 1 Summary of clinical data and investigations performed in conjunction with synovial biopsy

\begin{tabular}{|c|c|c|c|c|c|c|c|c|c|}
\hline \multirow[b]{2}{*}{ Case No } & \multirow[b]{2}{*}{ Age (y) } & \multirow[b]{2}{*}{$\operatorname{Sex}(M / F)$} & \multirow{2}{*}{$\begin{array}{l}\text { Morning } \\
\text { stiffness }\end{array}$} & \multicolumn{2}{|c|}{$R F$ concentration } & \multirow[b]{2}{*}{$H b(g \%)$} & \multirow{2}{*}{$\begin{array}{l}E S R \\
(\mathrm{~mm} / \mathrm{h})\end{array}$} & \multirow[b]{2}{*}{$x$ ray } & \multirow{2}{*}{$\begin{array}{l}\text { Biopsy } \\
\text { site }\end{array}$} \\
\hline & & & & $L x$ & $R-W$ & & & & \\
\hline \multicolumn{10}{|c|}{ Rheumatoid arthritis: } \\
\hline 1 & 61 & F & + & + & + & $12 \cdot 7$ & 105 & RA & R Knee \\
\hline 2 & 73 & $\mathbf{F}$ & + & + & + & 11.9 & ND & RA & L Knee \\
\hline 3 & 38 & $\mathbf{F}$ & + & + & + & $12 \cdot 3$ & 15 & RA & R Wrist \\
\hline 4 & 57 & $\mathbf{M}$ & + & + & - & 13.7 & ND & $\mathbf{R A}$ & L Wrist \\
\hline 5 & 77 & $\mathbf{M}$ & + & + & - & $10 \cdot 7$ & 118 & RA & R Elbow \\
\hline 6 & 46 & $\mathbf{F}$ & + & + & + & 13.5 & ND & RA & $R$ Wrist \\
\hline 7 & 35 & $\mathbf{M}$ & + & + & - & $13 \cdot 3$ & 37 & NAD & R Knee \\
\hline 8 & 56 & $\mathbf{F}$ & + & + & + & $13 \cdot 2$ & 28 & RA & $\mathbf{R}$ Hand \\
\hline 9 & 34 & $\mathbf{F}$ & + & + & + & $13 \cdot 1$ & 25 & RA & L Knee \\
\hline \multicolumn{10}{|c|}{ Osteoarthritis: } \\
\hline 10 & 43 & $\mathbf{F}$ & - & ND & ND & $13 \cdot 2$ & ND & OA & R Hip \\
\hline 11 & 77 & $\mathbf{F}$ & - & ND & ND & $12 . \overline{5}$ & ND & OA & R Hip \\
\hline 12 & 77 & $\mathbf{F}$ & - & - & - & 13.8 & 24 & OA & L Hip \\
\hline 13 & 50 & $\mathbf{F}$ & - & - & - & $14 \cdot 3$ & 8 & OA & L Hip \\
\hline 14 & 62 & $\mathbf{F}$ & - & ND & ND & $12 \cdot 7$ & ND & $\mathrm{OA}$ & R Knee \\
\hline 15 & 68 & $\mathbf{F}$ & - & ND & ND & $12 \cdot 3$ & 6 & OA & R Hip \\
\hline \multicolumn{10}{|c|}{ Non-specific joint inflammation: } \\
\hline 16 & 12 & $\mathbf{F}$ & - & - & - & $12 \cdot 5$ & 9 & NAD & R Ankle \\
\hline 17 & 18 & $\mathbf{F}$ & + & - & ND & $13 \cdot 7$ & 15 & NAD & R Knee \\
\hline 18 & 28 & $\mathbf{M}$ & - & - & - & $15 \cdot 5$ & 5 & NAD & R Ankle \\
\hline
\end{tabular}

RF = rheumatoid factor; $\mathrm{Lx}=$ Latex agglutination test; $\mathrm{R}-\mathrm{W}=$ Rose-Waller test; $\mathrm{Hb}=$ blood haemoglobin concentration in grams per decilitre; ESR = erythrocyte sedimentation rate in millimetres per hour; $N D=$ not done; $R A=$ diagnostic or grams per decilitre; $\mathrm{ESR}=$ erythrocyte sedimentation rate in millimetres per hour; $\mathrm{ND}=$ not done; $\mathrm{RA}=$ diagnostic
consistent with rheumatoid arthritis, $\mathrm{OA}=$ diagnostic or consistent with osteoarthritis; $\mathrm{NAD}=$ nothing abnormal discovered.

rehydrated. After the addition of trypsin, and blocking non-specific antibody binding with normal swine serum at a dilution of 1 in 20 , the BU38 monoclonal antibody (The Binding Site Ltd, Birmingham) was applied to the sections at a dilution of 1 in 100. Control sections of the same specimens were stained with another ascitic fluid antibody, BU31, which recognises an antigen associated with nuclear envelopes. A standard alkaline phosphatase anti-alkaline phosphatase (APAAP) detection system was used. The bridging antibody used was a rabbit anti-mouse immunoglobulin reagent (Dakopatts; No Z259) at a dilution of 1 in 50. The APAAP complex (Dakopatts; No D651) was used at a dilution of 1 in 100. A second cycle of bridging antibody and APAAP complex was performed. All antibody incubations were performed for 30 minutes. The chromogen was prepared freshly before use by dissolving $25 \mathrm{mg}$ naphthol AS-BI phosphate (Sigma; No $\mathrm{N} 2250$ ) in $1 \mathrm{ml}$ dimethylformamide, adding this to $50 \mathrm{mg}$ levamisole (Sigma; No L9756) in $50 \mathrm{ml} 0.05 \mathrm{M}$ TRIS buffer ( $\mathrm{pH} \mathrm{8.7)}$ ), and then adding $50 \mathrm{mg}$ Fast Red TR salt (Sigma; No F1500). The sections were incubated in this solution for 20 minutes at room temperature, washed, counterstained in Mayer's haematoxylin and then mounted in an aqueous medium.

All the sections were examined by two pathologists (EH and DCR) who assessed the degree of positivity (negative, weak, moderate or strong) and the percentage of lymphoid cells stained (none, less than $50 \%$, more than $50 \%$ but less than $90 \%$ and more than $90 \%$ ).

\section{Results}

Table 1 gives a summary of the clinical data concerning all the patients with joint disease included in this study. All of the patients who had been classified as having rheumatoid arthritis on clinical grounds were positive for rheumatoid factor, and all but one had radiological changes consistent with rheumatoid arthritis.

The results of the immunohistochemical staining on all of the specimens investigated is summarised in table 2. CD23 expression was moderately or strongly positive in $50 \%$ or more lymphocytes in six of the nine cases of rheumatoid arthritis. Two of the cases of rheumatoid arthritis, however, were negative for CD23, and in the remaining case only a small proportion of the lymphocytes in the inflammatory infiltrate were positive (figure). There was no apparent relation between CD23 positivity and age, sex, or disease activity, as measured by haemoglobin concentration and ESR at the time of the biopsy.

In the group of six biopsy specimens from patients with osteoarthritis one showed no CD23 staining, one had weak staining, two showed moderate staining and two showed strong staining in more than $50 \%$ of the lymphocytes. There was also a spectrum of weak to strong CD23 positivity in the three synovial biopsy specimens considered to show non-specific inflammation. There was moderate or strong CD23 positivity of more than $50 \%$ in all of the specimens showing chronic inflammation in non-articular tissues. None of these patients had any evidence of joint disease.

In both synovial and non-articular tissues that had pronounced CD23 positivity in lymphocytes, there was $\mathrm{CD} 23$ positivity in endothelial cells of small vessels within the region of the inflammation. Vessels away from areas of lymphoid infiltrate and in biopsy specimens with no or only weak CD23 positivity did not show this CD23 staining.

\section{Discussion}

Recent research has focused on the role of cytokines in rheumatoid arthritis, because these molecules may be responsible for the recruitment of cells and their activation within 
Table 2 Assessment of CD23 positivity in lymphocytes from each of the biopsy specimens studied

\begin{tabular}{|c|c|c|c|c|}
\hline Case No & Nature of biopsy & Site of biopsy & $\begin{array}{l}\text { Percentage of } \\
\text { lymphocytes positive }\end{array}$ & $\begin{array}{l}\text { Degree of } \\
\text { positivity }\end{array}$ \\
\hline $\begin{array}{c}\text { Rheumato } \\
1 \\
2 \\
3 \\
4 \\
5 \\
6 \\
7 \\
8 \\
9\end{array}$ & $\begin{array}{l}d \text { arthritis: } \\
\text { Synovium } \\
\text { Synovium } \\
\text { Synovium } \\
\text { Synovium } \\
\text { Synovium } \\
\text { Synovium } \\
\text { Synovium } \\
\text { Synovium } \\
\text { Synovium }\end{array}$ & $\begin{array}{l}\text { R Knee } \\
\text { L Knee } \\
R \text { Wrist } \\
\text { L Wrist } \\
R \text { Elbow } \\
R \text { Wrist } \\
R \text { Knee } \\
R \text { Hand } \\
\text { L Knee }\end{array}$ & $\begin{array}{c}50 \%-90 \% \\
50 \%-90 \% \\
50 \%-90 \% \\
0 \% \\
>90 \% \\
<50 \% \\
50 \%-90 \% \\
0 \% \\
50 \%-90 \%\end{array}$ & $\begin{array}{l}+++ \\
+++ \\
++ \\
+ \\
+++ \\
+ \\
+++ \\
+++\end{array}$ \\
\hline $\begin{array}{l}\text { Osteoarth } \\
10 \\
11 \\
12 \\
13 \\
14 \\
15\end{array}$ & $\begin{array}{l}\text { itis: } \\
\text { Synovium } \\
\text { Synovium } \\
\text { Synovium } \\
\text { Synovium } \\
\text { Synovium } \\
\text { Synovium }\end{array}$ & $\begin{array}{l}\text { R Hip } \\
\text { R Hip } \\
\text { L Hip } \\
\text { L Hip } \\
\text { R Knee } \\
\text { R Hip }\end{array}$ & $\begin{array}{l}>90 \% \\
>90 \% \\
0 \% \\
50 \%-90 \% \\
50 \%-90 \% \\
<50 \%\end{array}$ & $\begin{array}{l}+++ \\
+++ \\
+ \\
++ \\
++ \\
+\end{array}$ \\
\hline $\begin{array}{l}\text { Non-speci } \\
16 \\
17 \\
18\end{array}$ & $\begin{array}{l}\text { ic joint inflammation: } \\
\text { Synovium } \\
\text { Synovium } \\
\text { Synovium }\end{array}$ & $\begin{array}{l}\text { R Ankle } \\
\text { R Knee } \\
\text { R Ankle }\end{array}$ & $\begin{array}{l}<50 \% \\
<50 \% \\
>90 \%\end{array}$ & $\begin{array}{l}+ \\
+++ \\
+++\end{array}$ \\
\hline $\begin{array}{l}\text { Non-artic } \\
19 \\
20 \\
21 \\
22 \\
23\end{array}$ & $\begin{array}{l}\text { lar lesions: } \\
\text { Skin } \\
\text { Gallbladder } \\
\text { Branchial Cyst } \\
\text { Stomach (Gastritis) } \\
\text { Ileum (Crohn's) }\end{array}$ & & $\begin{array}{l}50 \%-90 \% \\
50 \%-90 \% \\
>90 \% \\
>90 \% \\
50 \%-90 \%\end{array}$ & $\begin{array}{l}+++ \\
+++ \\
+++ \\
+++ \\
++\end{array}$ \\
\hline
\end{tabular}
positive.

the joint. The synovial fluid from patients with rheumatoid arthritis has been shown to contain interleukin-1, ${ }^{23-25}$ granulocyte-macrophage colony stimulating factor, ${ }^{26}$ macrophage colony stimulating factor ${ }^{27}$ and a protein with similar properties to murine B cell growth factor $2 .^{28} \mathrm{In}$ contrast, $\gamma$ interferon ${ }^{29}$ and interleukin $-2^{78}$ are found only in small quantities in the synovial fluid from these patients. Similar changes in the concentrations of these cytokines, however, are found in other chronic arthritides such as psoriatic and juvenile arthritis. ${ }^{26}$ Thus changes in the concentrations of these cytokines are not specific to rheumatoid arthritis.

CD23 is a B lymphocyte activation marker and its soluble derivative has been shown to have effects on B cell growth and differentiation. ${ }^{12} \mathrm{~B}$ cell activation has been suggested as an important pathogenic factor in rheumatoid arthritis, so $\mathrm{CD} 23$ is a candidate for involvement in the inflammatory cell infiltrate in the disease.

Many monoclonal antibodies have been raised against CD23, but are limited in their use as reagents for immunohistochemistry because they do not work on sections of paraffin wax embedded tissues. The antibody used in this study is unique in that it shows CD23 antigen in this type of specimen. Two distinct forms of the CD23 molecule have been shown, but these differ only in their intracytoplasmic regions. ${ }^{30}$ BU38 recognises an epitope on the extracellular IgE binding part of the molecule, and so would be expected to bind to both forms of the membrane bound protein and to soluble CD23.

This study found CD23 positivity on lymphocytes in synovial biopsy specimens from most but not all patients with rheumatoid arthritis. There was no apparent correlation between the degree of CD23 staining and the activity of the disease as assessed by the ESR and the haemoglobin concentration. There was also no difference in CD23 staining between rheumatoid arthritis and other conditions showing chronic inflammation, both articular and non-articular. These findings suggest that CD23 expression is not of any specific pathogenetic importance in rheumatoid arthritis, but may be a characteristic feature of any chronic inflammatory response.

The finding of cytoplasmic endothelial staining in regions of $\mathrm{CD} 23$ positive cellular infiltrate is similar to that found in a previous study. ${ }^{23}$ It is believed that this phenomenon is due to uptake of soluble CD23 by endothelial cells.

The results of this study suggest that CD23 is found in all forms of chronic inflammation
Sections showing chronic inflammatory cell infiltrate in synovial tissue stained with an immunoalkaline phosphatase method using the anti-CD23 primary antibody $B U 38$. ( $A$ ) $A$ case of rheumatoid arthritis. Note that most lymphocytes show positivity for $C D 23$. ( $B$ $A$ different case of rheumatoid arthritis that is negative for $C D 23$.

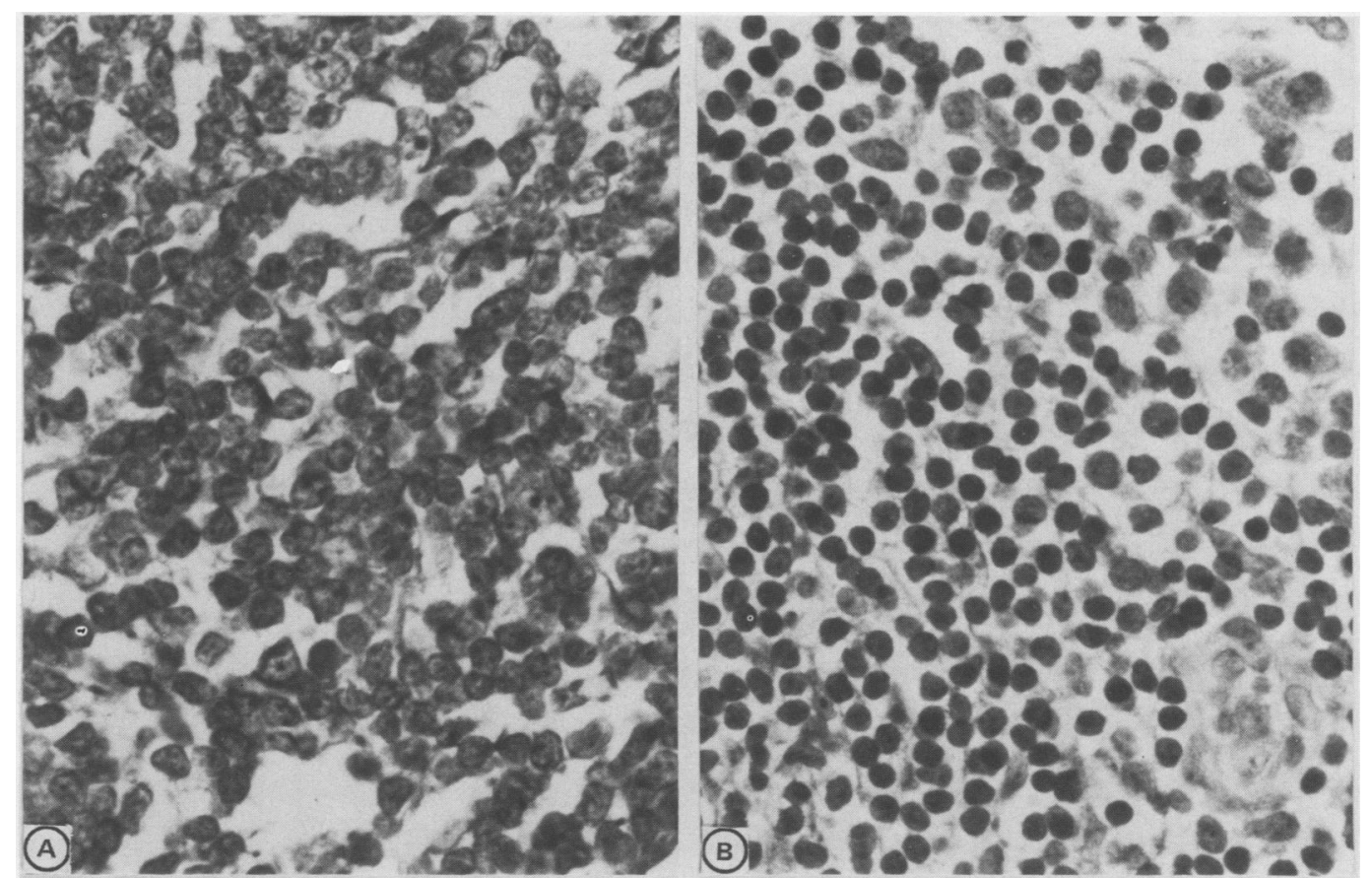


and is not likely to be specific for any particular form of chronic inflammatory disease. As CD23 was found on the surface of lymphocytes in many cases of these arthritides, however, sCD23 in serum or synovial fluid may still be a useful marker for the severity of the inflammatory infiltrate.

This study was supported by a grant from the West Midlands Regional Health Authority.

1 Duke O, Panayi GS, Janossy G, Poulter LW. An immunohistological analysis of lymphocyte subpopulations and their microenvironment in the synovial membranes of
patients with rheumatoid arthritis using monoclonal patients with rheumatoid arthritis using
antibodies. Clin Exp Immunol 1982;49:22-30.

2 Kurosaka M, Ziff M. Immunoelectron microscopic study of the distribution of $T$ cell subsets in rheumatoid synovium $J$ Exp Med 1983;158:1191-210.

3 Lindblad S, Hedfors E. The synovial membrane of healthy individuals-immunohistochemical overlap with synovitis. Clin Exp Immunol 1987;69:41-7.

4 Lindblad S, Hedfors $\mathrm{E}$. Arthroscopic and immunohistologic characteristics of knee joint synovitis in osteo-arthritis. Characteristics of knee joint synovit
Arthritis Rheum 1987;30:1081-8.

5 Stastny P. Association of the B cell alloantigen DRw4 with rheumatoid arthritis. $N$ Engl J Med 1978;298:869-71.

6 Zoschke D, Segall M. Dw subtypes of DR4 in rheumatoid arthritis: Evidence for a preferential association with Dw4 arthritis: Evidence for a prefere

7 Combe B, Pope RM, Fischbach M, Darnell B, Baron S, Talal N. Interleukin-2 in rheumatoid arthritis: production of and response to interleukin-2 in rheumatoid synovial fluid, synovial tissue and peripheral blood. Clin Exp Immunol 1985;59:520-8.

8 Combe B, Andary M, Klein B, Clot J, Sany J. Regulation of interleukin 2 production in rheumatoid arthritis. $J$ Rheumatol 1987;14:226-9.

9 Tosata G, Steinberg AD, Yaechoan R, et al. Abnormally elevated frequency of Epstein Barr Virus infected cells in the blood of patients with rheumatoid arthritis. J Clin the blood of patients

10 Depper JM, Bleustein HG, Zvaifler NJ. Impaired regulation of Epstein-Barr virus induced lymphocyte proliferation in rheumatoid arthritis is due to a $\mathrm{T}$ cell defect. $J$ Immunol 1981;127:1899-902.

11 Depper JM, Zvaifler NJ. Epstein-Barr virus: its relationship to the pathogenesis of rheumatoid arthritis. Arthritis Rheum 1981;24:755-61.

12 Gordon J, Flores-Romo L, Cairns JA, et al. CD23: a multifunctional receptor/lymphokine? Immunol Today 1989;10:153-7.

13 Thorley-Lawson DA, Mann KP. Early events in EpsteinBarr virus infection provide a model for $B$ cell activation. $J \operatorname{Exp}$ Med 1986;162:45-59.
14 Gordon J, Guy GR. The molecules controlling B lymphocytes. Immunol Today 1987;8:339-44.

15 Kikutani H, Inui S, Sato R, et al. Molecular structure of human lymphocyte receptor for immunoglobulin E. Cell human lymphocy

16 Yukawa K, Kikutani H, Owaki H, et al. A B cell specific differentiation antigen $\mathrm{CD} 23$ is a receptor for IgE (F\&\&R) on lymphocytes. J Immunol 1987;138:2576-80.

17 Thorley-Lawson DA, Swendeman SL, Edson CM. Biochemical analysis suggests distinct functional roles for the blast-1 and blast-2 antigens. $J$ Immunol 1986;136: 1745-51.

18 Lee BW, Simmons CF, Wileman T, Geha RS. Intracellular cleavage of newly synthesized low affinity $\mathrm{Fc} \varepsilon$ receptor (Fc\&R2) provides a second pathway for the generation of the 28-kDa soluble FceR2 fragment. J Immunol 1989;142:1614-20.

19 Gordon J, Rowe M, Walker L, Guy G. Ligation of the CD23, p45 (Blast 2, EBVCS) antigen triggers the cellcycle progression of activated B lymphocytes. Eur $J$ cycle progression of acti

20 Cairns J, Flores-Romo L, Millsum MJ, et al. Soluble CD23 is released by $\mathrm{B}$ lymphocytes cycling in response to interleukin 4 and anti-Bp50 (CDw40). Eur J Immunol 1988;18:349-53.

21 Uchibaysashi N, Kikutani H, Barsumian EL, et al. Recom binant soluble Fce receptor II (FceRII/CD23) has IgE binding activity but no $B$ cell growth promoting activity. $J$ Immunol 1989;142:3901-8.

22 Rowlands DC, Hansel TT, Crocker J. Immunohistochemical determination of CD23 expression in Hodgkin's disease using paraffin sections. J Pathol 1990;160:239-43.

23 Fontana A, Hengartner H, Weber E, Feur K, Grob PJ Cohen G. Interleukin-1 activity in the synovial fluid of patients with rheumatoid arthritis. Rheumatol Int patients with

24 Miossec $P$, Dinarello CA, Ziff $M$. Interleukin-1 lymphocyte chemotactic activity in rheumatoid arthritis synovial fluid. Arthritis Rheum 1983;29:461-9.

25 Wood DD, Ihrie EJ, Dinarello CA, Cohen PL. Isolation of an interleukin 1 like factor from human joint effusions. Arthritis Rheum 1983;26:975-83.

26 Firestein GS, Zvaifler NJ. The pathogenesis of rheumatoid arthritis. Rheum Dis Clin North Am 1987:447-59.

27 Firestein GS, Xu WD, Townsend K, et al. Cytokines in chronic inflammatory arthritis. I. Failure to detect $\mathrm{T}$-cell lymphokines (interleukin 2 and interleukin 3 ) and presence of macrophage colony stimulating factor $(\mathrm{CSF}$ presence of macrophage colony stimulating factor (CSF1) and a novel mast cell growth factor

28 Cohen AH, Redelman D, Zvaifler N. Characterization of rheumatoid arthritis B-cell growth factors. Arthritis Rheum 1984;27:S35.

29 Firestein GS, Zvaifler NJ.Peripheral blood and synovial fluid monocyte activation in inflammatory arthritis. II. Low levels of synovial fluid and synovial tissue interferon suggest that gamma interferon is not the primary macrophage activating factor. Arthritis Rheum 1987:30:864-71.

30 Yokota A, Kikutani $\mathrm{H}$, Tanaka $\mathrm{T}$, et al. Two species of human $F c \varepsilon$ receptor II (FceRII/CD23): Tissue-specific and IL-4-specific regulation of gene expression. Cell 1988;55:611-18. 